\title{
Improvement of Core Course Experiments in Biological Specialty in Newly-upgraded Local Universities
}

\author{
Yihong $\mathrm{Hu}^{1,2, a *}$, Wenshuai Zeng ${ }^{1,2, \mathrm{~b}}$, Chenzhong Jin ${ }^{1,2, \mathrm{c}}$, Xujiao Zhang ${ }^{1,2, \mathrm{~d}}$, Yong Chen ${ }^{1,2, \mathrm{e}}$ \\ ${ }^{1}$ Hunan Provincial Collaborative Innovation Center for Field Weeds Control, Loudi 417000, Hunan, China \\ ${ }^{2}$ Key Laboratory of Harmless Application of Pesticide in Hunan Higher Education, Hunan University of Humanities, Science and \\ Technology, Loudi 417000, Hunan, China

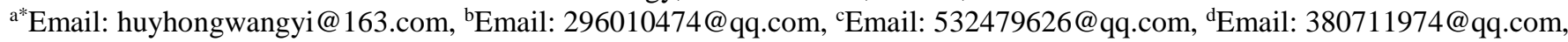 \\ eEmail: henon@163.com \\ *Corresponding author
}

\begin{abstract}
The core courses for biological specialty play a key role in talents cultivation in universities, and the teaching effects of core course experiments are closely associated with the quality of talents cultivation. In this paper, the actual conditions of experiment teaching and arrangement of the core courses for biological specialty in the newly-upgraded local universities were analyzed, and some of the valuable experience was introduced to the local universities such as Anhui Science and Technology University, Hunan University of Art and Sciences, and Hunan University of Humanities, Science and Technology to overcome these obstacles. The main measures include setting up reasonable core courses as well as core course experiments, properly integrating core course experiments, improving the levels of experimental teaching staffs, and making better use of the practical training platforms thus to provide valuable references for universities of the same kind.
\end{abstract}

Keywords-Biological specialty; Newly-upgraded local universities; Core course experiments; Talents cultivation

\section{INTRODUCTION}

Transitional development of the local universities is significant for higher education reform in China to date [1]. Early in 2016, the central government explicitly pointed out the ordinary undergraduate institutions should be transited to the applied type of colleges and universities. More specifically speaking, the objectives of personnel cultivation of specialties in these universities should be changed and should be aiming at both the local needs and the student employments. This transition should be based on locality, application, and distinctive feature. A large number of local universities were originated from the teachers' colleges and technical colleges. Generally, the biological specialties in these newly-upgraded local universities were settled simply according to the mode of comprehensive universities, and the core causes of these specialties were just a copy from the comprehensive universities.

The biological specialties are a category of specialties mainly including the biology science specialty, the biological engineering specialty, and the biological technology specialty, etc. The biological specialties which the newly-upgraded local universities can set are listed in TABLE I. In each specialty, the core courses always including from three to five courses which play an important role on culturing the vocational ability and professional quality of undergraduate students. Consequently, the experiment teaching and arrangement of core courses in these specialties may influence the location of specialty and the quality of talents cultivation. Therefore, based on the current conditions of experiment teaching and arrangement of the core courses in the biological specialties in the newly-upgraded local universities, we explored the construction and improvement on the experiment teaching system of these core courses in order to cultivate qualified talents for the local economic development more efficiently. 
TABLE I. BIOLOGICAL SPECIALTIES CAN BE SET IN THE NEWLY-UPGRADED LOCAL UNIVERSITIES

\begin{tabular}{|c|c|c|c|}
\hline No. & Specialty Code & Specialty & talents cultivation orientation \\
\hline 1 & 070401 & Biology science $^{\mathrm{a}}$ & Teacher-training \\
\hline 2 & 070402 & Biological technology $^{\mathrm{a}}$ & Scientific research \\
\hline 3 & 081801 & Biological engineering $^{\mathrm{a}}$ & Engineering \\
\hline 4 & 070410 & Animal biological technology & $\begin{array}{l}\text { Teacher-training and scientific } \\
\text { research }\end{array}$ \\
\hline 5 & 070409 & Plant biological technology & $\begin{array}{l}\text { Teacher-training and scientific } \\
\text { research }\end{array}$ \\
\hline 6 & 070411 & Biological resources science & Scientific research and application \\
\hline 7 & 070412 & Biology security & Scientific research and application \\
\hline 8 & 070407 & Biology science and biological technology & $\begin{array}{l}\text { Teacher-training and scientific } \\
\text { research }\end{array}$ \\
\hline 9 & 071402 & Ecology & Scientific research \\
\hline 10 & 090106 & Plant science and technology & $\begin{array}{c}\text { Agricultural and biotechnical } \\
\text { technician }\end{array}$ \\
\hline 11 & 090108 & Applied biology science & $\begin{array}{c}\text { Agricultural and biotechnical } \\
\text { technician }\end{array}$ \\
\hline 12 & 090501 & Animal science & $\begin{array}{c}\text { Agricultural and biotechnical } \\
\text { technician }\end{array}$ \\
\hline 13 & 040308 & Applied biology education & Teacher-training \\
\hline
\end{tabular}

\section{ACTUAL STATE OF EXPERIMENT TEACHING AND} ARRANGEMENT OF CORE COURSES IN BIOLOGICAL SPECIALTIES

\section{A. Core courses are settled without locality}

Since most of the newly-upgraded local universities were originated from the technical colleges or teachers' colleges or merged from these colleges, these universities were not guided with suitable theories of university management and running and did not settle a proper orientation at the beginning [2-3]. With limited knowledge and few experiences, these universities preferred to choose a mode of comprehensive university to set up core courses for the biological specialties. As usual, the core courses of the biological specialties in these newly-upgraded local universities are settled including the four engineering courses: genetic engineering, enzyme engineering, cell engineering, and fermentation engineering, which are frequently opened in the similar specialties in comprehensive universities. In comprehensive universities, the personnel training target is aiming at cultivating innovative and scientific researching talents, whereas in the local universities, they should lay more emphasis on the students' vocational ability in order to provide talents for the local economic construction. Simple copying and simulating of the settlement of core courses from comprehensive universities do not highlight the local characteristics in teaching.

\section{B. Quality of core experiment teaching is low}

The core courses are simply copied from the comprehensive universities whereas the teaching staffs in the local universities and the attached teaching hardware are far from satisfactory compared with those of the universities. This tactics seems simple and convenient, but obviously deviates from the target of the transitional development orientation of the local universities, and it is difficult to show the locality, application, and distinctive feature of the local universities. These settlements will result in the fact that the core course experiments are not adapted to the realistic needs. In addition, the situation will continue for several years once after the cultivating plan is set. As a result, the effects of experiment teaching of core courses cannot reach the levels of the comprehensive universities, causing a poor experiment teaching result.

\section{Constitution of experiment teaching staffs is not reasonable}

Owing to the inertia of the technical colleges or teachers' colleges, the experiment teaching staffs are always located as experiment teaching assistant kind and these people often do not own higher education background. Under this environment and guided by the backward experiment teaching idea, skilled teachers with higher degree are not willing to work in laboratories in these university, seriously hindering the development of innovative experiments in the core courses.

\section{IMPROVEMENT OF CORE COURSE EXPERIMENTS}

\section{A. Set up courses according to local needs}

Core courses reflect the orientation of talents cultivation and should be set up according to the local needs for talents, and the types of experiments should be considered also according the future job skill requirements of the undergraduate students in the future. For example, there are three biological specialties in Anhui Science and Technology University: the biology science specialty, the biological technology specialty, and the animal biological technology specialty. In the biology science specialty (for teacher training), the core courses are cell biology, molecular biology, human anatomy and physiology, plant physiology, and ecology, and the experiment types are mainly belonging to the verified experiments. In the biological technology specialty, which is emphasized on biopesticide and plant biological technology, the core courses are genetic engineering, cell engineering, protein engineering and enzyme engineering, microbiology 
engineering, and the experiment types are mainly the comprehensive type. In the animal biological technology specialty, the course of biotechnological pharmaceutics is added to train animal pharmaceutics technical ability. Then the core course experiments tighten the connections between the professional needs for skill and the practical ability. In this way, the talents in the three specialties will adapt the development of the local economics, and the running of biological specialties will be closely based on locality, application, and distinctive feature.

\section{B. Integrate core course experiments}

The biological technology specialty in Hunan University of Humanities, Science and Technology was set up in 2007. At that time, the teaching plan was drawn according to that of Hunan Normal University. The core courses of the specialty were genetic engineering, fermentation engineering, cell engineering, and enzyme engineering, and the core course experiments were also chosen and simplified from the experiment items of the specialty in Hunan Normal University. After several years of running, the teachers in the biological engineering teaching and research office were gradually aware that this arrangement was not suitable to cultivate biological talents, especially in experimental skills and professional skills. When the students further studied for master's degree after graduation, some of them fed back the information that their professional knowledge and experimental skills were not prepared well during undergraduate study. The personnel departments of the enterprises such as Hunan Ava Seeds Co. and Hunan Zhongshi Biotech Co. also reflected that the students they enrolled should reinforce their vocational skills urgently.

After investigation, the solution for the situation was put forward. On the basis of the original courses, a new course biopharmaceutics was added to the core courses. And the core course experiments were reselected and rearranged, and were integrated to a new individual experiment course, i.e. the biotechnology comprehensive experiments. In this experiment course, four comprehensive experiments was selected including detection and expression of an exogenous gene in Escherichia coli, screening and activity determination of alkaline protease producing strains, isolation, purification and identification of peroxidase from sweet potato and the preparation of enzyme production. And the teachers also published a relative textbook titled Agricultural Biotechnology Course to cover these experiments. After several years of practice and reform, the recognition degree of graduates from the biological specialty was promoted significantly by the society and enterprises.

\section{Improve levels of experiment teaching staffs}

The low levels and degrees of experiment teaching staffs restrict the teaching results of core experiments in the newlyupgraded local universities. Then how to improve the abilities of experiment teaching staffs becomes an urgent issue in front of the newly-upgraded local universities. Hunan University of Art and Sciences has gained experiences since upgraded in 1999. In the biological specialties, there are nine experiment teachers, and they are divided into three groups: teaching and assistant work group, equipment and environment assurance group, and technical development group. Among them, the teachers with the duty of teaching and assistant work are mainly in charge of daily experiment teaching, and most of them graduated from technical schools or colleges; the teachers with the duty of equipment and environment assurance are engineers and good at adjusting and repairing equipments, and most of them have master's degree; the teachers with the duty of technical development are senior engineers or professors, most of them have Ph.D titles, and they can design and improve the equipments and develop innovative experiments. With the active participation of the three levels of experiment staffs, the teaching results of core course experiments have been obviously promoted than before, and the graduates majored in biological specialties are warmly welcome by the local areas.

\section{Build innovative biological teaching platform}

Innovative training centers or bases are the approaches to cultivate the practical ability and innovative ability for undergraduate students [4-5]. In recent years, Hunan University of Humanities, Science and Technology has been cooperated with local government and enterprises, and built a serial of teaching bases and platforms (TABLE II, TABLE III). In 2015, Hunan University of Humanities, Science and Technology applied successfully a provincial innovative training center, the Demonstration Base of Agricultural and Biological Specialties for Talents Cultivation through Cooperation between University and Enterprises. Since then, the university has been cooperating with Hunan Jiulong Economic and Trade Co., Hunan Ava Seeds Co., and Hunan Zhongshi Biotech Co. etc. to train undergraduate students in biological specialties. The students not only carry out offcampus practical training in enterprises, but also do scientific researches in the laboratory under the supervision of their guiding teachers. Their scientific projects come from the real practical production, and some new experiments which are comprehensive and practical will be developed and added to the core experiment courses. For example, the fermentation of Antrodia cinnamomea was a key procedure for medicinal fungus processing in a local scale enterprise, the microbiology teachers in this university organized the practical training, and tackled the key technological problem in practice. Then they set up a new comprehensive experiment about the fermentation of $A$. cinnamomea including the whole procedures of sterilization, secondary enlargement, and usage of fermentation tank, and added it to the core course experiment items. Relying on this innovative biological teaching platform, the contents of core experiments are in constant change, enriched, and more suitable to the social needs. 
TABLE II. COOPERATED UNITS WITH HUNAN UNIVERSITY OF HUMANITIES, SCIENCE AND TECHNOLOGY

\begin{tabular}{|l|l|c|c|}
\hline \multicolumn{1}{|c|}{ No. } & \multicolumn{1}{c|}{ Cooperated units } & type & Cooperation direction \\
\hline 1 & Hunan Jiulong Economic and Trade Co. & Agriculture and biotechnology & Tissue culture \\
\hline 2 & Hunan Ava Seeds Co. & Agriculture and biotechnology & Seeds processing \\
\hline 3 & Hunan Zhongshi Biotech Co. & Biotechnology & $\begin{array}{c}\text { Microbiology, edible and } \\
\text { medicinal fungi technology }\end{array}$ \\
\hline 4 & Hunan Haili Chemical Industry Co. & Agriculture and biotechnology & Biological synthesis \\
\hline 5 & Hunan Lianyuan Fengleyuan Biotech Co. & Friculture and biotechnology & Food preservation technique \\
\hline 6 & Guizhou Liping Boyuan Biotech Co. & $\begin{array}{c}\text { Purification and production of } \\
\text { natural products }\end{array}$ \\
\hline 7 & Hunan Jinhan Milk Development Co. & Graduation practice \\
\hline 8 & $\begin{array}{l}\text { Lianyuan Qiaotouhe Science and Technology Industrial } \\
\text { Park }\end{array}$ & $\begin{array}{c}\text { Comprehensive practical training } \\
\text { base }\end{array}$ & Graduation practice \\
\hline 9 & Hunan Xiaolaye Food Co. & Biotechnology and Food & Food preservation technique \\
\hline 10 & Jialong Biotech (Lianyuan) Co. & Biotechnology & production of natural products \\
\hline
\end{tabular}

TABLE III. TEACHING PLATFORMS RELATED TO CULTURING TALENTS IN BIOLOGY SPECIALTIES IN HUNAN UNIVERSITY OF HUMANITIES, SCIENCE AND TECHNOLOGY

\begin{tabular}{|c|c|c|c|}
\hline No. & Base & Approved time & Approved institution \\
\hline 1 & Key Construction Discipline of Agricultural Pharmacology & 2012 & $\begin{array}{l}\text { Hunan Educational } \\
\text { Department }\end{array}$ \\
\hline 2 & $\begin{array}{l}\text { Key Laboratory of Harmless Application of Pesticide in Hunan } \\
\text { Higher Education }\end{array}$ & 2011 & $\begin{array}{l}\text { Hunan Educational } \\
\text { Department }\end{array}$ \\
\hline 3 & $\begin{array}{l}\text { Hunan Provincial Collaborative Innovation Center for Field } \\
\text { Weeds Control }\end{array}$ & 2014 & $\begin{array}{l}\text { Hunan Educational } \\
\text { Department }\end{array}$ \\
\hline 4 & $\begin{array}{l}\text { Demonstration Base of Agricultural and Biological Specialties } \\
\text { for Talents Cultivation through Cooperation between } \\
\text { University and Enterprises }\end{array}$ & 2015 & $\begin{array}{l}\text { Hunan Educational } \\
\text { Department }\end{array}$ \\
\hline 5 & $\begin{array}{l}\text { Provincial VR Teaching and Demonstration Center for } \\
\text { Agronomy and Biotechnology }\end{array}$ & 2016 & $\begin{array}{l}\text { Hunan Educational } \\
\text { Department }\end{array}$ \\
\hline
\end{tabular}

\section{SUMMARY}

In this study, we analyzed the actual state of experiment teaching and arrangement of core courses in the biological specialties in the newly-upgraded local universities, and introduced the helpful experiences from some local universities. Through setting up reasonable core courses and core course experiments, properly integrating core course experiments, improving the levels of the experiment teaching staffs, and making use of practical training platform, the teaching effects of core course experiments will be promoted, and the transitional development of the newly-upgrade local universities will be stimulated and put forward towards the right orientations of locality, application, and distinctive feature.

\section{ACKNOWLEDGMENT}

This research was financially supported by Innovation Base for Postgraduates Cultivation of Hunan Province (2261602) and Research Project of Teaching Reform of Degree and Graduate Education in Hunan (JG2016B106).

\section{REFERENCES}

[1] Y. Zhang, and H. Jiang, "Reflections on the challenges confronting china's municipal colleges in transition," Modern University Education, vol. 150, pp. 1-7, 2014.

[2] Y. Zhou, W. Jin, C. Chen, L. Chen, and F. Qiu, "Construction and practice of biology-majored practice teaching system in local higher colleges," Journal of East China Institute of Technology (Social Science Edition), vol. 27, pp. 87-90, 2008.

[3] G. Liu, S. Chai, L. Zhou, Y. Ding, and F. Chen, "On the establishment of the practical teaching system for biology majors in local universities," Journal of Huizhou University (Social Science Edition), vol. 28, pp. 98101, 2008.

[4] Q. Lin, "Exploration on practical education of demonstration bases for talents cultivation via school-enterprise cooperation," Journal of Heihe University, vol. 9, pp. 145-146, 2017.

[5] B. Zheng, S. Shen, N. Huang, J. Zeng, and H. Zhou, "Study on construction foundation of talent training demonstrative base on school enterprise cooperation," Guangzhou Chemical Industry, vol. 43, pp. 201 202, 2015. 